\title{
Explaining Ethnic, Racial, and Immigrant Differences in Private School Attendance ${ }^{1}$
}

\author{
Julian R. Betts \\ Department of Economics, University of California, San Diego, 9500 Gilman Drive, \\ La Jolla, California 92093-0508 and Public Policy Institute of California \\ E-mail: betts@ppic.org \\ and \\ Robert W. Fairlie \\ Department of Economics, University of California, Santa Cruz, Santa Cruz, \\ California 95064 and Joint Center for Poverty Research, Northwestern \\ University and University of Chicago \\ E-mail: rfairlie@cats.ucsc.edu
}

Received May 30, 2000; revised October 27, 2000; published online February 8, 2001

Using 1990 Census microdata, we explore ethnic, racial, and immigrant differences in private school attendance. We find high rates of private school attendance among white natives, white immigrants, and Asian natives. In contrast, we find low private school rates among black and Hispanic natives and immigrants. Asian immigrants, and other natives. Variations in income per capita and especially parental education account for over $70 \%$ of the gap in private school attendance rates between white natives and all other groups. We discuss ramifications for racial, language, and socioeconomic segregation in America's schools and possible effects of school vouchers on segregation. (c) 2001 Academic Press

\section{INTRODUCTION}

Private school vouchers are perhaps the most hotly debated topic in current discussions of educational reform. Critics have often argued that vouchers for private school tuition will lead to increased racial segregation in the nation's schools. On the other hand, proponents contend that vouchers available to all students or vouchers targeted to only low-income students may reduce segregation as differences in parental income become less important in determining who attends private school.

${ }^{1}$ This research was funded by the Extramural Research Program at the Public Policy Institute of California. We thank Dan Goldhaber, Jan Brueckner, two anonymous referees, and seminar participants at the fall 1999 meetings of the Association for Public Policy Analysis and Management, the Bay Area Labor Economists meetings, McMaster University, and the University of Toronto for helpful comments. Steve Anderson provided excellent research assistance. 
Central to the disagreement over the effects of vouchers on school segregation is the observation that ethnic, racial, and immigrant groups differ markedly in their propensities to attend private school. For example, in 1990 we found that $15.2 \%$ of native-born Asian schoolchildren attended private school, whereas only $4.4 \%$ of immigrant Hispanic schoolchildren attended private school. Are these large differences in private school attendance due to differences in income or are they primarily due to other factors? The answer to this question may provide insights into the effects of private school vouchers on school segregation. The question also bears on the capacity of the $\mathrm{K}-12$ sector, taken as a whole, to integrate immigrant schoolchildren.

Specifically, if income explains a significant portion of the gap in private school enrollment rates, then vouchers directed toward disadvantaged populations and therefore implicitly largely directed toward minorities might help to equalize attendance rates among groups. On the other hand, if other factors less amenable to change through public policy explain most of the variation in private school choice then vouchers might achieve little if any reduction in the observed gaps in private school attendance among groups. Examples of such factors are parental education, traits of the city of residence, and a wide array of factors that comprise parents' knowledge and belief systems.

Our central question thus concerns the role of income in explaining intergroup variations in private school attendance. This question is compelling only to the extent that private and public schools differ meaningfully in the quality of education provided. It is therefore significant that a growing body of literature suggests that attendance at private schools can lead to better outcomes, at least among disadvantaged and urban populations. ${ }^{2}$ Peer group effects may explain part of these variations in outcomes. ${ }^{3}$

${ }^{2}$ See Evans and Schwab [6], Neal [15], Sander and Krautmann [19], and Figlio and Stone [8]. Neal [15] finds that the impact of Catholic schools on high school and college graduation tends to be higher for urban blacks and Hispanics than for urban whites and especially for nonurban whites. Similarly, Figlio and Stone [8] find evidence that private schools may increase the educational attainment of urban minority populations more than that of the population at large. Evans and Schwab [6] report slightly higher effects for blacks relative to whites and for urban relative to suburban populations. It is unclear as to whether nonreligious private schools are as effective as Catholic schools. However, Catholic schools represent a large share of all private schools. For instance, in 1987, Catholic schools accounted for 53\% of all private school enrollment in the country, with nonsectarian schools accounting for only 16\%. (National Center for Education Statistics, [14], p. 66). Figlio and Stone [8] find evidence that Catholic schools are associated with better outcomes than are public schools, but that a positive effect for other private schools was harder to detect, perhaps due to the smaller number of students enrolled in such schools. The authors, however, report larger positive nonreligious school treatment effects for college attendance and selectivity of college outcomes than they report for Catholic schools. Finally, these studies focused on blacks or blacks and Hispanics as subgroups and did not examine Asian students or the relative importance of private school for immigrants and natives.

${ }^{3}$ See Summers and Wolfe [20] and Henderson et al. [9] for two well-known studies that document the existence of peer-group effects. 
In this paper, we use 1990 Census microdata to document and explore the underlying causes of ethnic, racial, and immigrant differences in private school attendance. To the best of our knowledge, this study marks the first attempt to study variations in private school choice between natives and immigrants. We find high rates of private school attendance among white natives, white immigrants, and Asian natives. Groups with substantially lower private school rates are black and Hispanic natives and immigrants, Asian immigrants, and other natives. These ethnic, racial, and immigrant differences are notably reduced after controlling for group differences in income, parental education, and other individual, school, and and geographical area characteristics. We find that differences in household income and parental education across racial/immigrant groups account for a large part of the differences in private school rates.

\section{DATA}

The data used in this study are from the Public Use Microdata 5-Percent Sample of the 1990 Censuses of Population. This data set is the only source of national microdata large enough to allow comparisons across many ethnic, racial, and immigrant groups. Furthermore, with observations for nearly two million schoolchildren it is possible to control for differences across a large number of metropolitan areas in the United States.

Our sample includes children ages 5 to 20 who are currently enrolled in primary or secondary school and who do not live in group quarters. We include only schoolchildren who live in one of the 132 Consolidated Metropolitan Statistical Areas (CMSAs, henceforth "metropolitan areas" or MAs) defined in Jaeger [10] and Bound and Holzer [2]. ${ }^{4}$ These metropolitan areas include $69 \%$ of all native-born schoolchildren in the United States and $93 \%$ of all immigrant schoolchildren. By focusing on this urban sample we are implicitly controlling for one of the main differences between native and immigrant children: immigrants are much less likely to live in rural areas in the United States. The use of this sample and the aforementioned MA codes also allows us to control for racial/immigrant differences in geographical locations. Notably, the aforementioned literature on the effect of private schools suggests that private schools "matter" more in urban areas than elsewhere.

We classify students as being enrolled in private or public school based on their responses to the school enrollment question on the Census. Note that the 1990 Census does not distinguish between religious and nonreligious private schools. ${ }^{5}$

\footnotetext{
${ }^{4}$ See Loeb et al. [12] for a description of the geographic codes. We thank these authors for providing their codes.

${ }^{5}$ Using the 1980 Census, in which there were separate categories, we find that $85.1 \%$ of children enrolled in private schools are enrolled in religious schools.
} 
We create 10 distinct racial/immigrant groups by interacting responses to the race, Spanish/Hispanic origin, and citizenship questions available in the Census. The groups are white (non-Hispanic) natives, white (non-Hispanic) immigrants, black natives, black immigrants, Hispanic natives, Hispanic immigrants, Asian natives, Asian immigrants, other natives, and other immigrants. ${ }^{6}$ Immigrants are defined as naturalized citizens and non-U.S. citizens. Natives are defined as those born in the United States, Puerto Rico, Guam, outlying areas, or abroad of American parents.

\section{PRIVATE SCHOOL ATTENDANCE BY RACIAL / IMMIGRANT GROUP}

Native-born children and immigrant children differ markedly in their average propensities to attend private school. In Table 1, we report private school rates by school type and immigrant status for our sample of 132 MAs. $^{7}$ The private school rate is defined as the fraction of all schoolchildren enrolled in private school. We distinguish between primary and secondary schools because private primary school rates are higher than private secondary school rates among both natives and immigrants.

The estimates in the second and third rows of Table 1 indicate that native-born children are substantially more likely than immigrant children to attend private school at both levels. Native schoolchildren are 4.3 percentage points or $56 \%$ more likely to attend a private primary school than are immigrant schoolchildren and are 3.9 percentage points or $63 \%$ more likely to attend a private high school.

There also exist large differences in private school attendance by ethnicity and race. In Table 1 and Figures 1 and 2 we report private school rates for nine distinct racial/immigrant groups. Two findings from this analysis are noteworthy. First, the distinction between native and immigrant groups within each race is important. Asian natives have the highest private secondary school rate and the second highest private primary school rate of any group. In contrast, Asian immigrants have two of the lowest private school rates. Native-born Hispanics also have substantially higher private school rates than immigrant Hispanics.

${ }^{6}$ Other natives consist primarily of American Indians. We drop the other immigrant category in most of the analyses below due to small sample sizes.

${ }^{7}$ Because the 1990 Census asks about the highest grade completed, not the current grade in which the student was enrolled, and because responses to grades 1-8 and 5-8 are grouped, we had to make some compromises when dividing the sample into secondary and primary school enrollees. Because of the grouped nature of the education variable, we had to include students likely to be enrolled in grade 9 in the primary education category. Similarly, we did not include students whose highest grade completed was kindergarten for fear of confusing grade 1 students with some students who might still be in preschool. Thus, below we will refer to students in grades 2-9 as "primary school" students, and students in grades 10-12 as "high school" or "secondary school" students, even though grade 8 more typically represents the year in which students leave primary/middle schools for high school. 
TABLE 1

Private School Rates by Racial/Immigrant Group: 1990 Census 132 MA Sample

\begin{tabular}{lrrrrr}
\hline & \multicolumn{2}{c}{ Primary school } & & \multicolumn{2}{c}{ Secondary school } \\
\cline { 2 - 3 } \cline { 5 - 6 } & Rate $(\%)$ & $N$ & & Rate $(\%)$ & \multicolumn{1}{c}{$N$} \\
\hline Total & 11.62 & 922,237 & & 9.71 & 337,964 \\
All natives & 11.83 & 876,980 & & 10.03 & 309,792 \\
All immigrants & 7.57 & 45,257 & & 6.17 & 28,172 \\
White natives & 13.78 & 603,507 & & 11.49 & 218,014 \\
White immigrants & 17.76 & 6,269 & & 13.84 & 3,608 \\
Black natives & 6.34 & 134,091 & & 5.05 & 48,974 \\
Black immigrants & 9.39 & 3,479 & & 5.79 & 2,175 \\
Hispanic natives & 8.52 & 109,025 & & 8.36 & 33,885 \\
Hispanic immigrants & 4.53 & 21,426 & & 4.20 & 12,797 \\
Asian natives & 15.33 & 23,461 & & 14.60 & 6,647 \\
Asian immigrants & 6.93 & 13,853 & & 6.02 & 9,432 \\
Other natives & 7.94 & 6,896 & & 6.39 & 2,272 \\
Other immigrants & 7.78 & 230 & & 1.88 & 160 \\
\hline
\end{tabular}

Note. The sample consists of children (ages 5-20) who are currently enrolled in school and who are not living in group quarters. The private school rate is the fraction of schoolchildren enrolled in private school.

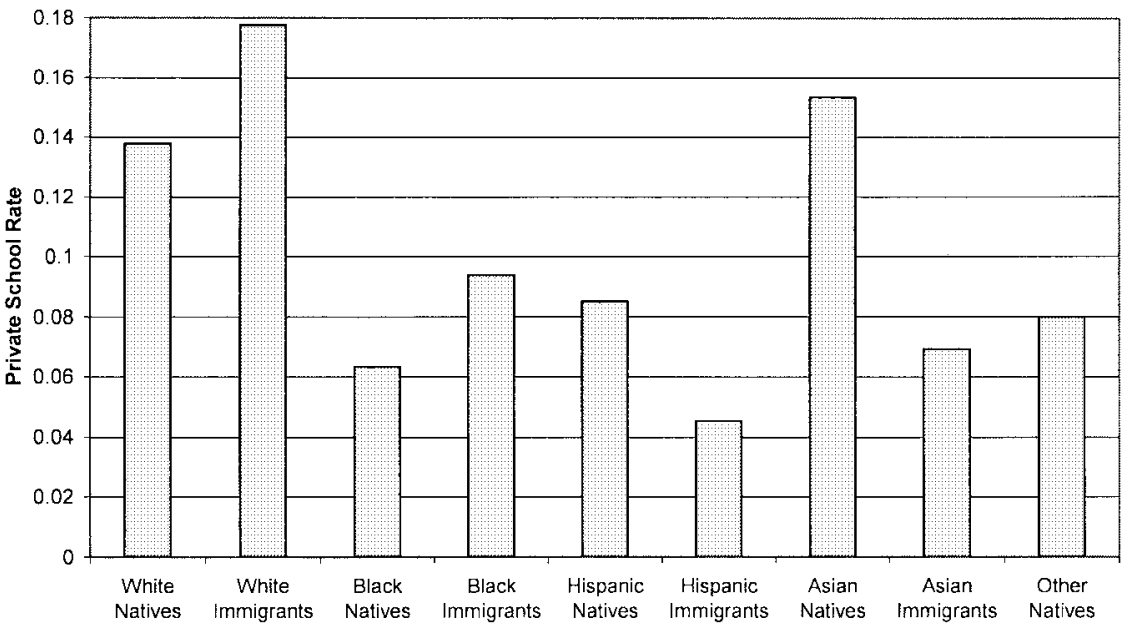

FIG. 1. Private school rates by racial/immigrant group (primary school): 1990 Census 132 MA sample. 


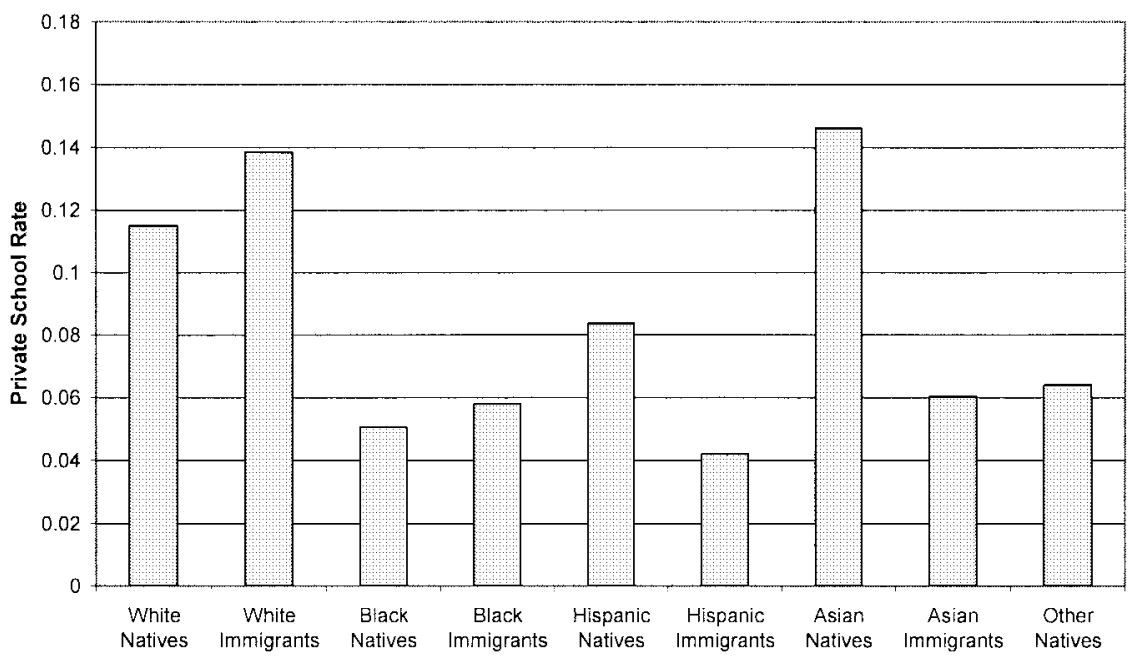

FIG. 2. Private school rates by racial/immigrant group (secondary school): 1990 Census 132 MA sample.

The opposite is true, however, for whites and blacks. For both racial groups, immigrant private school rates are higher than native rates.

The second important finding is that private school rates differ substantially by ethnicity and race. Holding immigrant status constant, white and Asian natives have much higher average probabilities of attending private school than black, Hispanic, or other natives. Among immigrant groups, whites have the highest rates and Hispanics have the lowest rates.

Because of the large differences in private school attendance between native-born and immigrant schoolchildren and across ethnic and racial groups, we use the nine distinct groups in the remainder of the analysis. These groups are also likely to differ greatly in their financial resources, preferences for private education, and demands for special educational services, such as bilingual education, English as a Second Language programs, and Advanced Placement courses. Using these classifications, we find that private primary school rates range from $4.5 \%$ for Hispanic immigrants to $17.8 \%$ for white immigrants. Among high school students, Hispanic immigrants have the lowest rate $(4.2 \%)$ and Asian natives have the highest rate (14.6\%).

Two factors that may contribute to these patterns are group differences in household income and parental education. Table A-1 in the Appendix documents differences in household income and parental education by racial/immigrant group. The sample includes all primary and secondary schoolchildren. The estimates indicate substantial differences in household income between groups. For example, the average per-person household income among Asian 
native schoolchildren is $\$ 14,100$, which is approximately three times the average income among Hispanic immigrants of $\$ 5,100$. Blacks, Hispanics, and, to a lesser extent, Asian immigrants and other natives have low income levels relative to whites and Asian natives.

Table A-1 also indicates that the racial/immigrant patterns for parental education are generally similar to the pattern for income. Whites and Asian natives have high levels of parental education, whereas blacks and Hispanics have low levels of parental education. There are several differences, however. First, Asian immigrants have higher levels of parental education than white natives. Second, Hispanics have very low levels of parental education, which are lower than those among blacks.

Is there a relationship between private school rates and either income or parental education across the racial/immigrant groups? Figures 3 and 4 provide evidence for this question. In each figure, the size of the bubble is proportional to the group's sample size. Figure 3 reveals a positive relationship between the private school rate and average per-person household income. Figure 4 provides similar evidence of a positive relationship between the private school rate and mother's education across the nine racial/immigrant groups. Although not reported, a graph of private school rates against fathers' education shows a similarly strong pattern. This univariate analysis suggests that ethnic, racial, and immigrant differences in income and parental education may contribute to the large gaps in rates of private school attendance documented above.

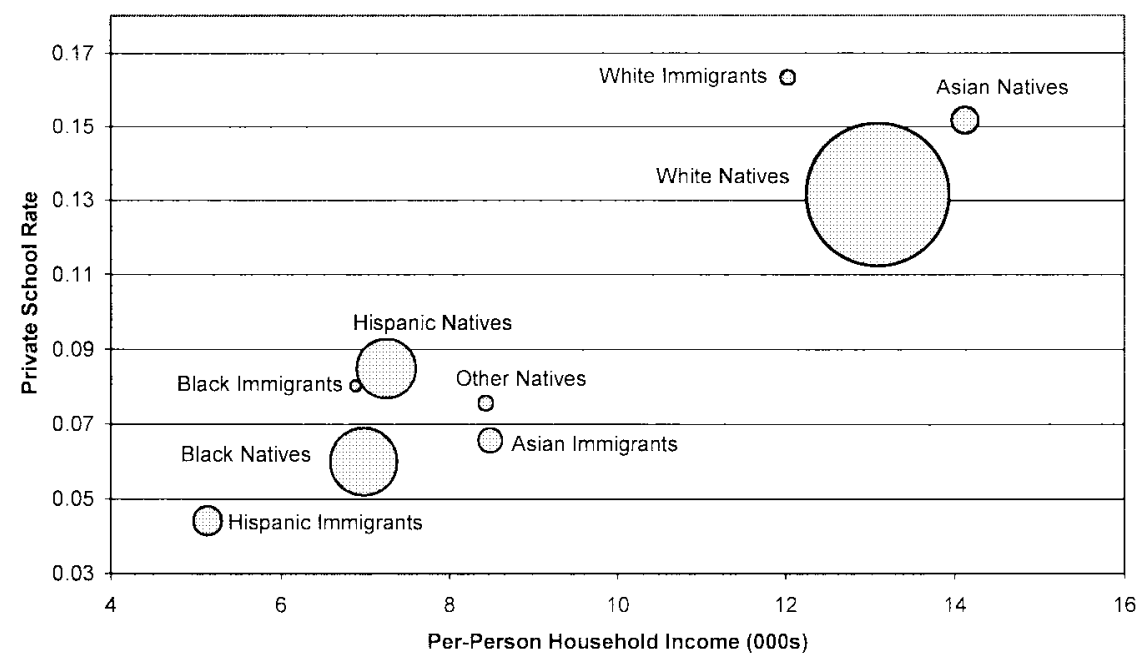

FIG. 3. Private school rate versus per-person household income by racial/immigrant group: 1990 Census 132 MA sample. 


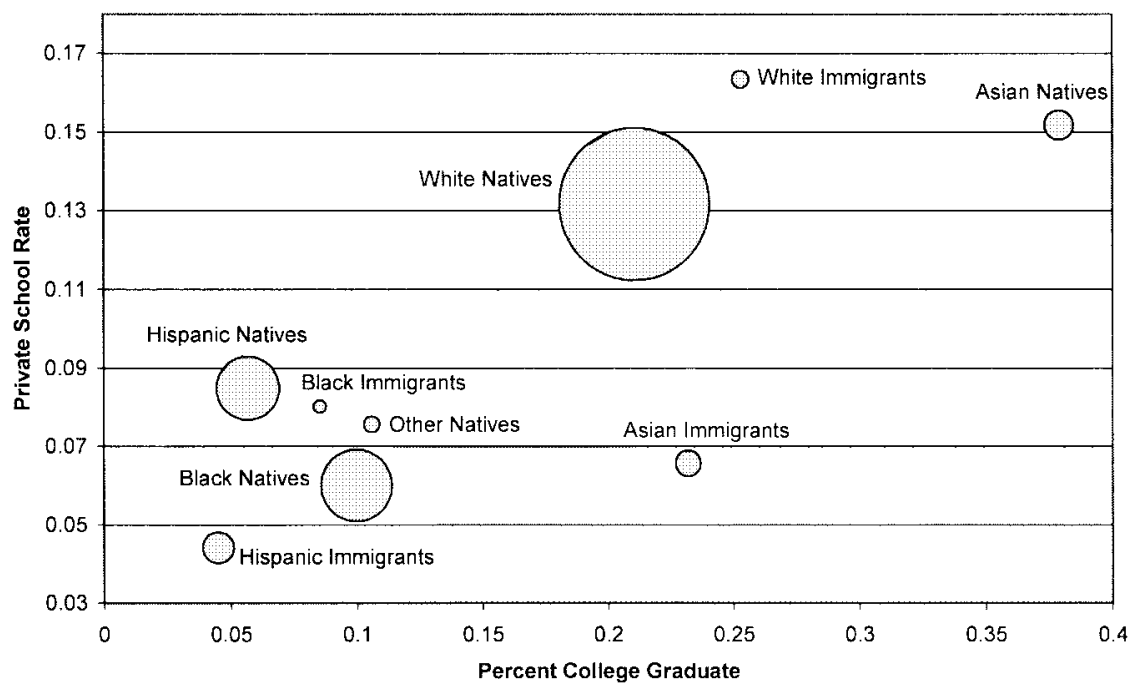

FIG. 4. Private school rate versus mother's education by racial/immigrant group: 1990 Census 132 MA sample.

\section{AN EMPIRICAL MODEL OF PRIVATE SCHOOL ATTENDANCE}

The results presented in Figures 3 and 4 suggest that ethnic, racial, and immigrant differences in household income and parental education may contribute to differences in private school rates. We are interested in formally testing this hypothesis and in determining whether these factors and others have large effects. We also want to move toward a multivariate analysis in which we can identify the separate effects of household income and parental education. We accomplish these goals by estimating equations for the probability of attending private school using our sample of schoolchildren.

We first specify a reduced form equation for the private/public school decision. The equation determining private school attendance for individual $i$ in MA $m$ is

$$
Y_{i m}=Z_{i m} \gamma+D_{i m} \lambda+\alpha_{m}+\varepsilon_{i m},
$$

where $Y_{i m}$ equals 1 if the child attends private school and zero otherwise, $Z_{i m}$ is a row vector of individual-level characteristics (e.g., household income and parental education), $D_{i m}$ is a row vector of race/immigrant group dummy variables, $\alpha_{m}$ is a metropolitan area fixed effect, and $\varepsilon_{i m}$ is a disturbance term. The MA fixed effects are included to control for variation in school and 
geographical area characteristics, such as public school expenditures per pupil, private school student to teacher ratios, and local crime rates. ${ }^{8}$

We estimate (4.1) using a linear probability model. ${ }^{9}$ Separate estimates using our samples of primary school students and secondary school students are reported in Table 2. In specifications 1 and 3, we only include dummy variables for the nine racial/immigrant groups. The left-out group is white natives, so that the coefficient estimates capture the difference between the white native private school rate and the group's private school rate (referred to here as the relative private school rate). Therefore, the findings for ethnic, racial, and immigrant differences in private school attendance reflect those presented above. Black and Hispanic natives and immigrants and other natives are substantially less likely to attend private school than are white natives, whereas white immigrants and Asian natives are more likely to attend private school. The coefficients on the dummy variables for all of these groups are highly significant.

In specifications 2 and 4, we include measures of age, sex, parental education, and per-person household income in addition to the racial/immigrant group dummy variables. We also include MA fixed effects and dummy variables that indicate whether the mother, the father, or both are unidentified in these two specifications. We do not report the corresponding coefficients in order to conserve space. The individual-level variables included in these two specifications are comparable to those included in previous studies. We find that younger schoolchildren and girls are more likely to attend private school. As expected, per-person household income has a positive effect on the probability of attending private school. The coefficient estimates imply that an extra $\$ 1,000$ of income (evaluated at $\$ 11,000$ ) increases the private school attendance rates by 0.3 percentage point among primary school students and 0.2 percentage point among secondary school students. These appear to be large effects when the racial/immigrant differences in average income are taken into consideration. For example, they imply that an increase in income from the average value for Hispanic immigrants $(\$ 5,100)$ to the average value for Asian natives

\footnotetext{
${ }^{8}$ Previous studies of the determinants of school choice include these and other measures of school and local area characteristics. Although the inclusion of the MA fixed effects precludes us from estimating the separate effects of these variables, it has the advantage of controlling for all of these effects and the additional effects of unobserved school and local area characteristics.

${ }^{9}$ The linear structure of the decomposition described in the next section makes it very difficult to use a nonlinear method of estimating the probability of attending private school. Although it is well known that ordinary least squares (OLS) provides consistent parameter estimates when using a discrete dependent variable (see Maddala [13], for example), the fact that the predicted probabilities can lie outside the range of 0 to 1 can be a concern. Therefore, we compare our coefficient estimates to the average derivatives from a probit model. A simple regression of the OLS coefficient estimates on the probit average derivatives yields slope coefficients of 0.91 and 0.90 for the primary and secondary school regressions, respectively. The $R^{2}$ values for these regressions are 0.95 and 0.94 . By both counts, the OLS and probit models provide very similar predictions.
} 
TABLE 2

Linear Probability Models for Probability of Attending Private School: 1990 Census 132 MA Sample

\begin{tabular}{|c|c|c|c|c|}
\hline \multirow[b]{3}{*}{ Explanatory variables } & \multicolumn{4}{|c|}{ Specification } \\
\hline & \multicolumn{2}{|c|}{ Primary school } & \multicolumn{2}{|c|}{ Secondary school } \\
\hline & (1) & (2) & (3) & (4) \\
\hline White immigrants & $\begin{array}{c}0.0467 \\
(0.0040)\end{array}$ & $\begin{array}{c}0.0372 \\
(0.0039)\end{array}$ & $\begin{array}{c}0.0284 \\
(0.0049)\end{array}$ & $\begin{array}{c}0.0188 \\
(0.0048)\end{array}$ \\
\hline Black natives & $\begin{array}{r}-0.0722 \\
(0.0009)\end{array}$ & $\begin{array}{r}-0.0422 \\
(0.0010)\end{array}$ & $\begin{array}{r}-0.0622 \\
(0.0015)\end{array}$ & $\begin{array}{r}-0.0406 \\
(0.0016)\end{array}$ \\
\hline Black immigrants & $\begin{array}{r}-0.0400 \\
(0.0053)\end{array}$ & $\begin{array}{r}-0.0215 \\
(0.0053)\end{array}$ & $\begin{array}{r}-0.0522 \\
(0.0063)\end{array}$ & $\begin{array}{r}-0.0515 \\
(0.0062)\end{array}$ \\
\hline Hispanic natives & $\begin{array}{r}-0.0495 \\
(0.0010)\end{array}$ & $\begin{array}{c}0.0047 \\
(0.0012)\end{array}$ & $\begin{array}{r}-0.0297 \\
(0.0017)\end{array}$ & $\begin{array}{c}0.0175 \\
(0.0019)\end{array}$ \\
\hline Hispanic immigrants & $\begin{array}{r}-0.0880 \\
(0.0022)\end{array}$ & $\begin{array}{r}-0.0220 \\
(0.0023)\end{array}$ & $\begin{array}{r}-0.0694 \\
(0.0026)\end{array}$ & $\begin{array}{r}-0.0137 \\
(0.0029)\end{array}$ \\
\hline Asian natives & $\begin{array}{c}0.0208 \\
(0.0021)\end{array}$ & $\begin{array}{r}-0.0056 \\
(0.0021)\end{array}$ & $\begin{array}{c}0.0359 \\
(0.0036)\end{array}$ & $\begin{array}{r}-0.0029 \\
(0.0037)\end{array}$ \\
\hline Asian immigrants & $\begin{array}{c}-0.0647 \\
(0.0027)\end{array}$ & $\begin{array}{r}-0.0421 \\
(0.0027)\end{array}$ & $\begin{array}{r}-0.0510 \\
(0.0031)\end{array}$ & $\begin{array}{r}-0.0314 \\
(0.0031)\end{array}$ \\
\hline Other natives & $\begin{array}{r}-0.0586 \\
(0.0038)\end{array}$ & $\begin{array}{r}-0.0099 \\
(0.0037)\end{array}$ & $\begin{array}{r}-0.0485 \\
(0.0061)\end{array}$ & $\begin{array}{r}-0.0065 \\
(0.0060)\end{array}$ \\
\hline Other immigrants & $\begin{array}{r}-0.0665 \\
(0.0207)\end{array}$ & $\begin{array}{r}-0.0314 \\
(0.0202)\end{array}$ & $\begin{array}{r}-0.0914 \\
(0.0230)\end{array}$ & $\begin{array}{r}-0.0661 \\
(0.0224)\end{array}$ \\
\hline Age & & $\begin{array}{r}-0.0034 \\
(0.0001)\end{array}$ & & $\begin{array}{r}-0.0033 \\
(0.0004)\end{array}$ \\
\hline Female & & $\begin{array}{c}0.0060 \\
(0.0006)\end{array}$ & & $\begin{array}{c}0.0054 \\
(0.0010)\end{array}$ \\
\hline $\begin{array}{l}\text { Per-person household } \\
\text { income }(000 \mathrm{~s})\end{array}$ & & $\begin{array}{c}0.0032 \\
(0.0001)\end{array}$ & & $\begin{array}{c}0.0023 \\
(0.0001)\end{array}$ \\
\hline $\begin{array}{l}\text { Per-person household } \\
\text { income squared } / 100\end{array}$ & & $\begin{array}{c}0.0001 \\
(0.0001)\end{array}$ & & $\begin{array}{c}0.0005 \\
(0.0001)\end{array}$ \\
\hline Mother: high school graduate & & $\begin{array}{c}0.0224 \\
(0.0010)\end{array}$ & & $\begin{array}{c}0.0121 \\
(0.0016)\end{array}$ \\
\hline Mother: some college & & $\begin{array}{c}0.0458 \\
(0.0011)\end{array}$ & & $\begin{array}{c}0.0273 \\
(0.0017)\end{array}$ \\
\hline Mother: college graduate & & $\begin{array}{c}0.0702 \\
(0.0013)\end{array}$ & & $\begin{array}{c}0.0574 \\
(0.0020)\end{array}$ \\
\hline Father: high school graduate & & $\begin{array}{c}0.0026 \\
(0.0012)\end{array}$ & & $\begin{array}{r}-0.0002 \\
(0.0018)\end{array}$ \\
\hline Father: some college & & $\begin{array}{c}0.0222 \\
(0.0012)\end{array}$ & & $\begin{array}{c}0.0146 \\
(0.0019)\end{array}$ \\
\hline Father: college graduate & & $\begin{array}{c}0.0473 \\
(0.0014)\end{array}$ & & $\begin{array}{c}0.0508 \\
(0.0020)\end{array}$ \\
\hline Mean of dependent variable & 0.1126 & 0.1126 & 0.0944 & 0.0944 \\
\hline Sample size & 922,237 & 922,237 & 337,964 & 337,964 \\
\hline$R^{2}$ & 0.01 & 0.06 & 0.01 & 0.06 \\
\hline
\end{tabular}

Note. The sample consists of children (ages 5 to 20) who are currently enrolled in school and who are not living in group quarters. Standard errors are reported in parentheses. In addition to the reported variables, both equations include 132 metropolitan area fixed effects and dummies for whether the mother, father, or both are unidentified. 
$(\$ 14,100)$ results in increases in the private school attendance rates by 2.9 and 2.1 percentage points for primary and secondary schoolchildren, respectively. These predicted changes are meaningful but by no means bridge the actual gaps in private school attendance rates between these two groups of 10.8 and 10.4 percentage points in primary and secondary school, respectively.

To measure the effect of parental education on private school attendance, we include dummy variables indicating whether the child's mother graduated from high school, attended some college (but did not graduate), or graduated from college. The omitted category is not finishing high school. An analogous set of dummy variables is included for father's education. The predicted private school probability increases with higher levels of both mother's and father's education. The effects are large: for a given student having two college-educated parents relative to two high school graduate parents the effect is predicted to increase the probability of attending private school by 9.25 and 9.63 percentage points for primary and secondary students, respectively. These predicted gains are extremely large given that on average only 11.62 and $9.71 \%$ of students attend private schools at these two levels, respectively.

The inclusion of household income, parental education, the other individuallevel controls, and the MA fixed effects has a notable effect on the racial/immigrant dummy variables. This effect can readily be seen in Figs. 5 and 6, which report unadjusted and adjusted private school rates relative to the white

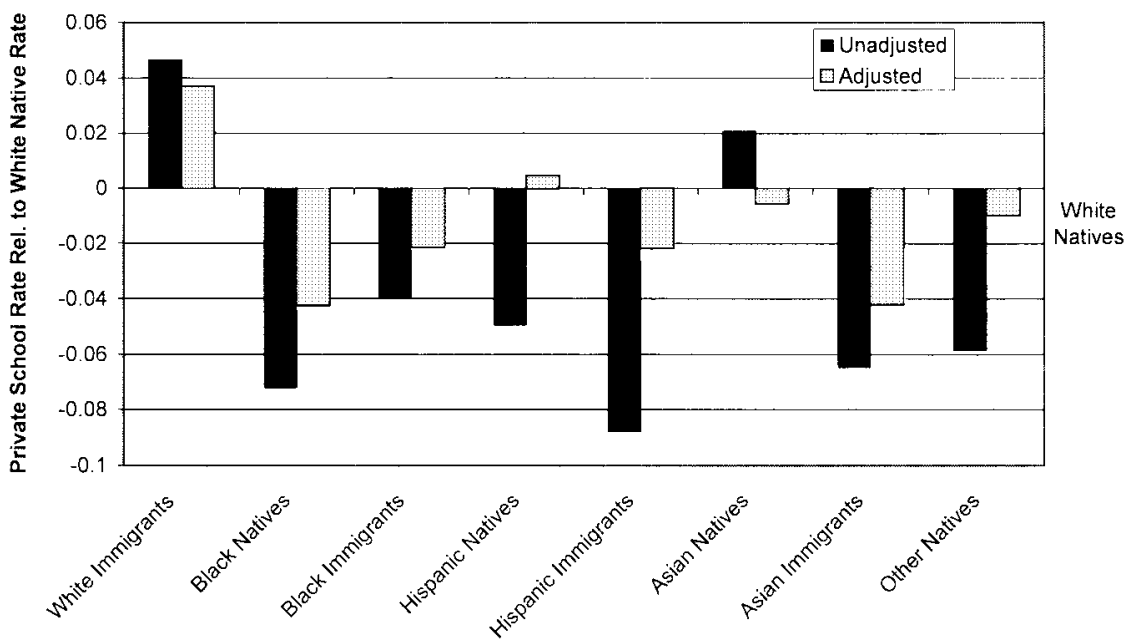

FIG. 5. Relative private school rates by racial/immigrant group (primary school): 1990 Census. 


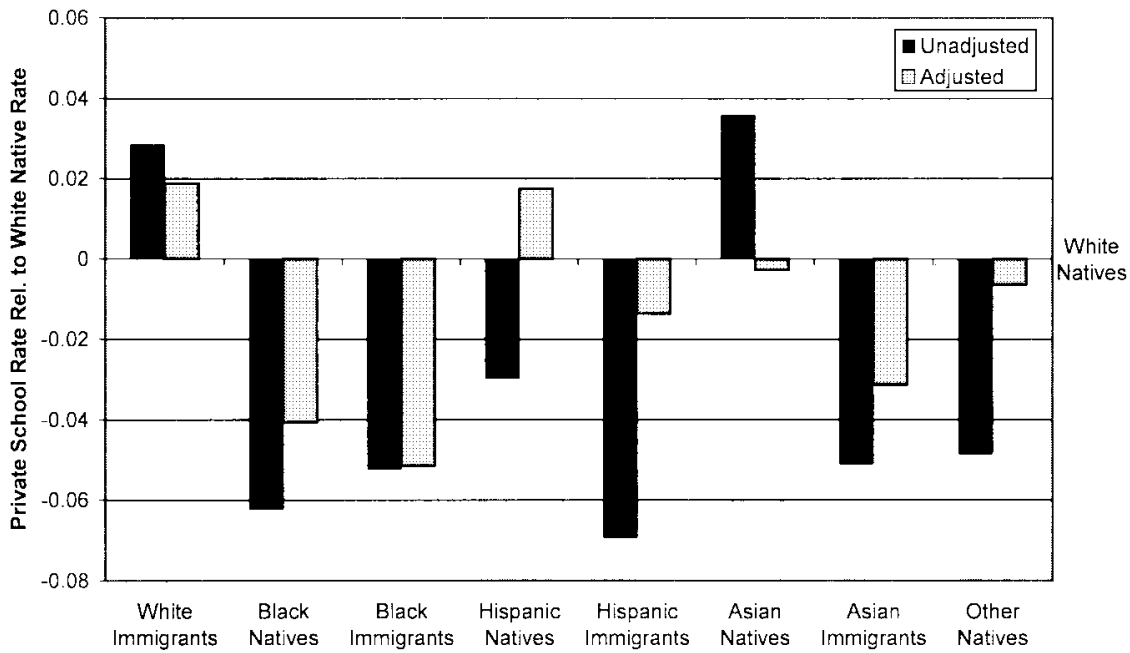

FIG. 6. Relative private school rates by racial/immigrant group (secondary school): 1990 Census.

native private school rate. ${ }^{10}$ The unadjusted private school rates are the racial/immigrant coefficient estimates from specifications 1 and 3 , and the adjusted private school rates are the coefficient estimates from specifications 2 and 4. For all racial/immigrant groups the adjusted private school rates are smaller in absolute value than the unadjusted private school rates. Furthermore, for many groups the adjusted private school rates are substantially smaller than the unadjusted rates, and for some groups the adjusted rates are very close to zero. Overall, these results indicate that our regression controls account for a substantial portion of the variation in private school attendance across racial/ immigrant groups.

The controls do a good job of explaining why Asian natives have higher private school rates than those of white natives and why Hispanic natives and immigrants and other natives have lower rates than those of white natives. In most cases, the adjusted private school rates for these groups are fairly close to zero. The estimates also indicate that differences in the control variables contribute to the high private school rates of white immigrants and the low rates of black natives and Asian immigrants. The adjusted private school rate for black immigrants is much lower than the unadjusted rate for primary school, but is only slightly lower than that for secondary school.

\footnotetext{
${ }^{10}$ We do not show results for "other immigrants" in this figure or in later decomposition tables because of the small sample size of this group.
} 
After controlling for differences in household income, parental education, and other variables, we find that the sign of the gap between private school attendance rates of white natives and each of the other racial/immigrant groups is unchanged. Two exceptions are Asian natives, who now have a slightly lower rate than white natives, and Hispanic natives, who have a slightly higher rate. Most of these differences from white natives' private enrollment rates remain significant at the 5\% level at least, the exceptions being Asian natives in secondary school, other natives in secondary school, and other immigrants in primary school.

Overall, our results at the national level are roughly consistent with those of Buddin et al. [3] for California schoolchildren. They do not examine immigrant status but find that being a U.S. citizen increases the probability of attending private school. They also find that blacks and Hispanics are more likely to attend private school, and Asians/Pacific Islanders are less likely to attend private school than are non-Hispanic whites after controlling for a large number of variables.

\section{DECOMPOSING THE ETHNIC, RACIAL, AND IMMIGRANT GAPS IN PRIVATE SCHOOL RATES}

The results presented in Table 2 and Figures 5 and 6 indicate that the large differences in private school rates between ethnic, racial, and immigrant groups can be explained in large part by differences in parental education, family income, and MA characteristics. The estimates, however, cannot identify the separate contributions from group differences in each of these variables.

To explore these issues further we employ a slight variant of the familiar technique of decomposing intergroup differences in a dependent variable into those due to different observable characteristics across groups and those due to different "prices" of characteristics of groups (see Blinder [4] and Oaxaca [17]). In particular, the difference between the private school rates of groups $g$ and $j$ can be expressed as

$$
\bar{Y}^{g}-\bar{Y}^{j}=\left(\bar{X}^{g}-\bar{X}^{j}\right) \hat{\beta}^{g}+\bar{X}^{j}\left(\hat{\beta}^{g}-\hat{\beta}^{j}\right),
$$

where $\bar{X}^{g}$ is a row vector of average values for the individual-level characteristics and the MA distribution and $\hat{\beta}^{g}$ is a vector of coefficient estimates for group $g$. The first term in the decomposition represents the part of the gap that is due to group differences in average values of the independent variables, and the second term represents the part due to differences in the group processes determining private school attendance. We further decompose the first term into the separate contributions from group differences in specific variables, such as income and parental education. The second term or "unexplained" portion 
relates to variations in the coefficients for specific variables across groups and includes the race/immigrant dummies. This unexplained portion cannot be similarly decomposed into separate contributions and is typically calculated by subtracting the first term in (5.1) from the total gap. ${ }^{11}$

An equally valid method of calculating the decomposition is to use the coefficient estimates for group $j$ (i.e., $\hat{\beta}^{j}$ ) as weights in estimating the contributions from group differences in the independent variables. This alternative method of calculating the decomposition often provides different estimates, which is the familiar index problem with the Blinder-Oaxaca decomposition technique.

A third alternative, used in Neumark [16] and Oaxaca and Ransom [18], is to weight the first term of the decomposition expression using coefficient estimates from a pooled sample of the two groups. We follow this approach to calculate the decompositions. In particular, we use coefficient estimates from a regression that includes a pooled sample of all racial/immigrant groups (using specifications 2 and 4 of Table 2). We then denote white natives as the base group and calculate the decomposition for the private school rate gap between native whites and each minority group. Thus, the first term in the decomposition that captures the explained variation in mean attendance rates between attendance group $j$ and the native white (NW) group is

$$
\left(\bar{X}^{\mathrm{NW}}-\bar{X}^{j}\right) \hat{\beta}^{*},
$$

where $\hat{\beta}^{*}$ are the pooled coefficients. The unexplained term in the decomposition is calculated by subtracting (5.2) from the total private school rate gap. This technique has two important advantages over the first two decomposition techniques. First, the use of the same coefficient estimates for weighting the explained part of the decomposition allows us to easily compare results across groups. Second, we avoid the problem of using imprecisely estimated coefficients for some of the smaller minority groups. This is especially important for the MA fixed effects as not all of these can be estimated separately by group because of a lack of observations in our group subsamples.

In Tables 3 and 4, we report the results from the decomposition of the private school rate gap between white natives and each minority group. We report separate contribution estimates for ethnic, racial, and immigrant differences in income, parental education, and the MA fixed effects. We also report the private school rate gap between native whites and each group and the unexplained part of the gap.

\footnotetext{
${ }^{11}$ The interpretation of this term for specific subsets of variables, such as parental education, is problematic because it is sensitive to the choice of the left-out category.
} 
We begin with an analysis of the ability of each factor to explain the overall gap in private attendance probabilities between white natives and all other students, as shown in the top rows of Tables 3 and 4 . In both primary and secondary schools, income per capita and parental education account for much of the gap in mean enrollment rates between white natives and other students. Differences in income per capita account for 29.3 and $36.2 \%$ of the gap in primary and secondary schools, respectively. The corresponding numbers for parental education are 43.7 and $37.2 \%$. In contrast, variations in personal controls (age and gender) account for virtually none of the variations in enrollment rates, essentially because these variables are similar across demographic groups. Variations in the MA fixed effects cannot explain any of the private school enrollment gap and in fact work in the "wrong" direction. That is, nonwhite native students tend to live in cities with higher overall shares of

\section{TABLE 3}

Decomposition of Racial/Immigrant Differences in Private School Rates: Primary School

\begin{tabular}{|c|c|c|c|c|c|c|c|}
\hline \multirow[b]{2}{*}{ Group } & \multirow{2}{*}{$\begin{array}{c}\text { Private } \\
\text { school } \\
\text { rate }\end{array}$} & \multirow{2}{*}{$\begin{array}{c}\text { Gap } \\
\text { relative } \\
\text { to white } \\
\text { natives }\end{array}$} & \multicolumn{4}{|c|}{ Contributions from group differences in } & \multirow[b]{2}{*}{$\begin{array}{c}\text { Un- } \\
\text { explained }\end{array}$} \\
\hline & & & Controls & Income & $\begin{array}{l}\text { Parental } \\
\text { education }\end{array}$ & MAs & \\
\hline $\begin{array}{l}\text { All except white } \\
\text { natives }\end{array}$ & 0.07636 & 0.05533 & $\begin{array}{l}-0.0007 \\
-1.3 \%\end{array}$ & $\begin{array}{l}0.01622 \\
29.3 \%\end{array}$ & $\begin{array}{l}0.02419 \\
43.7 \%\end{array}$ & $\begin{array}{l}-0.0040 \\
-7.2 \%\end{array}$ & $\begin{array}{l}0.01961 \\
35.5 \%\end{array}$ \\
\hline $\begin{array}{l}\text { White } \\
\text { immigrants }\end{array}$ & 0.17834 & -0.04665 & $\begin{array}{l}0.00107 \\
-2.3 \%\end{array}$ & $\begin{array}{l}0.00246 \\
-5.3 \%\end{array}$ & $\begin{array}{c}-0.00143 \\
3.1 \%\end{array}$ & $\begin{array}{l}-0.01156 \\
24.8 \%\end{array}$ & $\begin{array}{l}-0.03719 \\
79.7 \%\end{array}$ \\
\hline Black natives & 0.05951 & 0.07218 & $\begin{array}{l}-0.00070 \\
-1.0 \%\end{array}$ & $\begin{array}{l}0.01835 \\
25.4 \%\end{array}$ & $\begin{array}{l}0.02523 \\
35.0 \%\end{array}$ & $\begin{array}{l}-0.01291 \\
-17.9 \%\end{array}$ & $\begin{array}{l}0.04220 \\
58.5 \%\end{array}$ \\
\hline $\begin{array}{l}\text { Black } \\
\text { immigrants }\end{array}$ & 0.09169 & 0.03999 & $\begin{array}{l}0.00110 \\
2.7 \%\end{array}$ & $\begin{array}{l}0.01853 \\
46.3 \%\end{array}$ & $\begin{array}{l}0.02772 \\
69.3 \%\end{array}$ & $\begin{array}{l}-0.02886 \\
-72.2 \%\end{array}$ & $\begin{array}{l}0.02150 \\
53.8 \%\end{array}$ \\
\hline Hispanic natives & 0.08218 & 0.04950 & $\begin{array}{l}-0.00123 \\
-2.5 \%\end{array}$ & $\begin{array}{l}0.01748 \\
35.3 \%\end{array}$ & $\begin{array}{l}0.03099 \\
62.6 \%\end{array}$ & $\begin{array}{l}0.00693 \\
14.0 \%\end{array}$ & $\begin{array}{l}-0.00467 \\
-9.4 \%\end{array}$ \\
\hline $\begin{array}{l}\text { Hispanic } \\
\text { immigrants }\end{array}$ & 0.04369 & 0.08800 & $\begin{array}{l}0.00103 \\
1.2 \%\end{array}$ & $\begin{array}{l}0.02429 \\
27.6 \%\end{array}$ & $\begin{array}{l}0.04020 \\
45.7 \%\end{array}$ & $\begin{array}{l}0.00048 \\
0.5 \%\end{array}$ & $\begin{array}{l}0.02199 \\
25.0 \%\end{array}$ \\
\hline Asian natives & 0.15251 & -0.02082 & $\begin{array}{c}-0.00214 \\
10.3 \%\end{array}$ & $\begin{array}{c}-0.00408 \\
19.6 \%\end{array}$ & $\begin{array}{c}-0.01156 \\
55.5 \%\end{array}$ & $\begin{array}{c}-0.00862 \\
41.4 \%\end{array}$ & $\begin{array}{r}0.00558 \\
-26.8 \%\end{array}$ \\
\hline $\begin{array}{l}\text { Asian } \\
\text { immigrants }\end{array}$ & 0.06699 & 0.06470 & $\begin{array}{l}0.00183 \\
2.8 \%\end{array}$ & $\begin{array}{l}0.01367 \\
21.1 \%\end{array}$ & $\begin{array}{l}0.00948 \\
14.7 \%\end{array}$ & $\begin{array}{l}-0.00238 \\
-3.7 \%\end{array}$ & $\begin{array}{l}0.04210 \\
65.1 \%\end{array}$ \\
\hline Other natives & 0.07309 & 0.05860 & $\begin{array}{l}-0.00046 \\
-0.8 \%\end{array}$ & $\begin{array}{l}0.01513 \\
25.8 \%\end{array}$ & $\begin{array}{l}0.01931 \\
33.0 \%\end{array}$ & $\begin{array}{l}0.01470 \\
25.1 \%\end{array}$ & $\begin{array}{l}0.00992 \\
16.9 \%\end{array}$ \\
\hline
\end{tabular}

Note. The sample and coefficient estimates are the same as those reported in specification 2 of Table 2. See text for more details on calculation of decompositions. The controls include age and sex. The percentages refer to the percentage of the gap that is explained by the given factor. 
TABLE 4

Decomposition of Racial/Immigrant Differences in Private School Rates: Secondary School

\begin{tabular}{|c|c|c|c|c|c|c|c|}
\hline \multirow[b]{2}{*}{ Group } & \multirow{2}{*}{$\begin{array}{l}\text { Private } \\
\text { school } \\
\text { rate }\end{array}$} & \multirow{2}{*}{$\begin{array}{c}\text { Gap } \\
\text { relative } \\
\text { to white } \\
\text { natives }\end{array}$} & \multicolumn{4}{|c|}{ Contributions from group differences in } & \multirow[b]{2}{*}{$\begin{array}{c}\text { Un- } \\
\text { explained }\end{array}$} \\
\hline & & & Controls & Income & $\begin{array}{l}\text { Parental } \\
\text { education }\end{array}$ & MAs & \\
\hline All except white & 0.06582 & 0.0433 & 0.00003 & 0.01605 & 0.01650 & -0.00457 & 0.01631 \\
\hline natives & & & $0.1 \%$ & $36.2 \%$ & $37.2 \%$ & $-10.3 \%$ & $36.8 \%$ \\
\hline $\begin{array}{l}\text { White } \\
\text { immigrants }\end{array}$ & 0.13858 & -0.02843 & $\begin{array}{l}0.00001 \\
0.0 \%\end{array}$ & $\begin{aligned} & 0.00312 \\
- & 11.0 \%\end{aligned}$ & $\begin{array}{l}0.00033 \\
-1.2 \%\end{array}$ & $\begin{array}{c}-0.01305 \\
45.9 \%\end{array}$ & $\begin{array}{c}-0.01883 \\
66.2 \%\end{array}$ \\
\hline Black natives & 0.04796 & 0.06218 & $\begin{array}{c}-0.00002 \\
0.0 \%\end{array}$ & $\begin{array}{l}0.01786 \\
28.7 \%\end{array}$ & $\begin{array}{l}0.01707 \\
27.5 \%\end{array}$ & $\begin{array}{l}-0.01333 \\
-21.4 \%\end{array}$ & $\begin{array}{l}0.04061 \\
65.3 \%\end{array}$ \\
\hline $\begin{array}{l}\text { Black } \\
\quad \text { immigrants }\end{array}$ & 0.05793 & 0.05222 & $\begin{array}{l}0.00056 \\
1.1 \%\end{array}$ & $\begin{array}{l}0.01896 \\
36.3 \%\end{array}$ & $\begin{array}{l}0.02022 \\
38.7 \%\end{array}$ & $\begin{array}{l}-0.03906 \\
-74.8 \%\end{array}$ & $\begin{array}{l}0.05153 \\
98.7 \%\end{array}$ \\
\hline Hispanic natives & 0.08045 & 0.02970 & $\begin{array}{l}-0.00036 \\
-1.2 \%\end{array}$ & $\begin{array}{l}0.01678 \\
56.5 \%\end{array}$ & $\begin{array}{l}0.02213 \\
74.5 \%\end{array}$ & $\begin{array}{l}0.00863 \\
29.1 \%\end{array}$ & $\begin{array}{l}-0.01747 \\
-58.8 \%\end{array}$ \\
\hline $\begin{array}{l}\text { Hispanic } \\
\text { immigrants }\end{array}$ & 0.04079 & 0.06936 & $\begin{array}{l}0.00112 \\
1.6 \%\end{array}$ & $\begin{array}{l}0.02319 \\
33.4 \%\end{array}$ & $\begin{array}{l}0.02870 \\
41.4 \%\end{array}$ & $\begin{array}{l}0.00264 \\
3.8 \%\end{array}$ & $\begin{array}{l}0.01371 \\
19.8 \%\end{array}$ \\
\hline Asian natives & 0.14608 & -0.03593 & $\begin{array}{c}-0.00102 \\
2.8 \%\end{array}$ & $\begin{array}{c}-0.00496 \\
13.8 \%\end{array}$ & $\begin{array}{c}-0.01636 \\
45.5 \%\end{array}$ & $\begin{array}{l}-0.01647 \\
45.8 \%\end{array}$ & $\begin{aligned} & 0.00287 \\
- & 8.0 \%\end{aligned}$ \\
\hline $\begin{array}{l}\text { Asian } \\
\text { immigrants }\end{array}$ & 0.05916 & 0.05099 & $\begin{array}{l}0.00081 \\
1.6 \%\end{array}$ & $\begin{array}{l}0.01423 \\
27.9 \%\end{array}$ & $\begin{array}{l}0.00590 \\
11.6 \%\end{array}$ & $\begin{array}{l}-0.00133 \\
-2.6 \%\end{array}$ & $\begin{array}{l}0.03137 \\
61.5 \%\end{array}$ \\
\hline Other natives & 0.06162 & 0.04853 & $\begin{array}{l}-0.00003 \\
-0.1 \%\end{array}$ & $\begin{array}{l}0.01265 \\
26.1 \%\end{array}$ & $\begin{array}{l}0.01352 \\
27.9 \%\end{array}$ & $\begin{array}{l}0.01589 \\
32.8 \%\end{array}$ & $\begin{array}{l}0.00650 \\
13.4 \%\end{array}$ \\
\hline
\end{tabular}

Note. See note to Table 3.

students enrolled in private schools, and in spite of this fact these minorities remain less likely to attend such schools. ${ }^{12}$

The overall picture is clear, with variations in income per capita and, in particular, parental education, explaining large portions of the observed intergroup variations in private school enrollment rates. However, interesting patterns emerge within the immigrant and minority subgroups.

First, as noted above, white immigrants have higher private school rates than white natives. This gap in private school rates, however, remains mostly unexplained by group differences in the included variables. This is true at both the primary and secondary school levels. The only included factor that provides

\footnotetext{
${ }^{12}$ This may in part be due to "native flight" or "white flight" from public schools. See Betts and Fairlie [1] for evidence that a rise in the immigrant share of the school-aged population induces flight by native-born schoolchildren to private schools, and see Conlon and Kimenyi [5], Fairlie and Resch [7], Figlio and Stone [8], and Lankford and Wyckoff [11] for examples of studies finding evidence of white flight from public schools into private schools when the public schools have large concentrations of blacks or minorities.
} 
a substantial contribution is the MA differences. Apparently, white immigrants are more likely, on average, to live in MAs with higher private school rates than are white natives. ${ }^{13}$ Another interesting finding is that the private school rates for white immigrants would be slightly higher if not for the group's lower average income level relative to that of white natives.

Black native private school rates are substantially lower than white native rates. Approximately, $25 \%$ of this disparity in private school rates can be explained by lower levels of household income among black native schoolchildren. On average black native per capita household income levels are less than one-half white native income levels. Another factor that explains a large portion of the gap is the racial difference in parental education. Lower levels of parental education among black schoolchildren explain 35 and $28 \%$ of their lower private school rates in primary and secondary schools, respectively. Together, racial differences in income and parental education explain more than $50 \%$ of the gap in private school rates between white natives and black natives. Working in the opposite direction, however, black natives tend to live in MAs with higher private school rates than white natives. This result contributes to the finding that more than $50 \%$ of the gap in private school rates between the two groups remains unexplained by racial differences in the included variables.

Black immigrants also have lower private school rates than white natives, although the differences are not as large. For this group, lower income levels explain 46 and $36 \%$ of the gaps in private school rates at the primary and secondary levels, respectively. Lower levels of parental education explain even larger shares of the private school rate gaps. Therefore, controlling for these two factors eliminates the gap between white natives and black immigrants at the primary school level and explains $75 \%$ of the gap at the secondary school level. Black immigrants, however, tend to live in MAs with high private school rates, thus resulting in very large total unexplained portions of the gap for this group.

For Hispanic natives, low rates of private school attendance are due to the combination of low levels of income, parental education, and location in MAs with low private school rates. Income differences alone explain 35 and $57 \%$ of the gap at the primary and secondary levels, respectively. Racial differences in parental education, however, provide the largest contribution to the gap. They explain $63 \%$ of the primary school gap and $75 \%$ of the secondary school gap. The contributions from MA differences are much smaller.

As noted above, Hispanic immigrants have the lowest private school rate of all racial/immigrant groups. These low private school rates are primarily due

\footnotetext{
${ }^{13}$ As expected, based on the relatively small sample sizes for white immigrants, this result is not simply due to a concentration of white immigrants in an MA, thereby driving up its private school rate. The estimated contributions from group MA differences using white native coefficients instead of the pooled coefficients are very similar.
} 
to low levels of income and parental education. Racial differences in these two variables explain approximately $75 \%$ of the gap in private school rates between white natives and Hispanic immigrants. Again, the gap in parental education between this minority group and white natives is the more important factor.

Asian natives have higher private school rates than white natives. Fifty percent of this gap can be explained by the difference in parental education. Higher levels of income and a higher likelihood of living in MAs with high private school rates also contribute to the higher private school rates of Asian natives.

In contrast, Asian immigrants have substantially lower private school rates than those of white natives. This appears to be partly due to lower levels of income and parental education for this group. However, more than $60 \%$ of the gap remains unexplained.

Finally, the low private school rate of other natives appears to be due to the combination of lower levels of income and parental education and the concentration across MAs. These three factors explain $83 \%$ of the primary school racial gap and $87 \%$ of the secondary school racial gap.

The decomposition estimates indicate that group differences in income levels account for large percentages of the gaps in private school rates. This finding has not been previously documented and suggests that the high tuition costs of private schools are limiting the opportunities of some racial/immigrant groups to attend these schools. It also implies that vouchers targeted at low-income groups may have the effect of reducing some of the racial/immigrant group differences in private school attendance.

The racial/immigrant gaps in private school rates, however, are not entirely caused by differences in income levels. Differences in parental education are also important and in fact provide more explanatory power than do income gaps for the overall gap in private school attendance between white natives and minority groups in primary school, as shown in the top row of Table 3. Table 4 shows that parental education and income both explain about $36-37 \%$ of the overall enrollment gap in secondary school. The policy implications of the finding that parental education "matters" are not clear: differences in private school attendance may partly result from differences in parental knowledge, connections, ability, or even tastes.

\section{DOES THE EXPLANATORY POWER OF FAMILY INCOME AND PARENTAL EDUCATION VARY BY CHARACTERISTICS OF MAS?}

Our inclusion of MA fixed effects controls for any unobserved characteristics of metropolitan areas that might affect the decision to enroll in private school. The possibility remains, however, that certain MA traits might alter the impact of family income and parental education on the decision to enroll in private school. The key question is: do family income and parental education matter to 
varying degrees across different types of MAs in explaining the gap between private school enrollment rates of white natives and others? Two MA characteristics that previous literature suggests might influence the decision to send one's children to private school are the local crime rate and per pupil expenditures in public schools. Accordingly, we divide our 132 MAs into two groups of 66, consisting of low-crime and high-crime MAs. We also create two groups of MAs with high and low spending per pupil in public schools. We reestimate models 2 and 4 in Table 2 and the decomposition of the enrollment gap between white natives and all others for these subgroups of MAs. Details on the construction of these two MA traits appear in the Appendix.

Table 5 shows the share of white native children enrolled in private school in the four groups of MAs, for both primary and secondary schools. White native private enrollment rates at the primary level do not vary much between lowand high-crime MAs, but at the secondary level, the rate is about 0.6 percentage point higher in high-crime MAs. Somewhat surprisingly, white private enrollment rates are higher in MAs with relatively high spending per pupil in public schools. Of course, these differences in enrollment rates reflect many factors, including differences in the average characteristics of the white native families themselves.

Table 6 shows the decomposition results when we run the models on the samples of low-crime and high-crime MAs, respectively. In both primary and secondary schools, the gap in the private school enrollment between white natives and all others was higher in high-crime MAs than in low-crime MAs. The decomposition analysis at both school levels suggests that parental education and household income per capita can explain a larger portion of the enrollment gap in high-crime MAs. But the increase in explanatory power is far larger for the income variable. For instance, in primary schools the percentage

TABLE 5

White Native Private School Rates in MAs with Low and High Crime Rates and Public School Spending Rates

\begin{tabular}{lcc}
\hline Type of MAs & $\begin{array}{c}\text { Primary } \\
\text { schools (\%) }\end{array}$ & $\begin{array}{c}\text { Secondary } \\
\text { schools (\%) }\end{array}$ \\
\hline Low-crime MAs & 13.23 & 10.68 \\
High-crime Mas & 13.12 & 11.30 \\
MAs with low public school & 11.21 & 9.02 \\
$\quad$ spending per pupil & 14.55 & 12.33 \\
MAs with high public school & & \\
$\quad$ spending per pupil & & \\
\hline
\end{tabular}

Note. The 132 MAs were divided into two groups of 66 MAs, based on crime rates in one case and public school spending per pupil in the other case. 


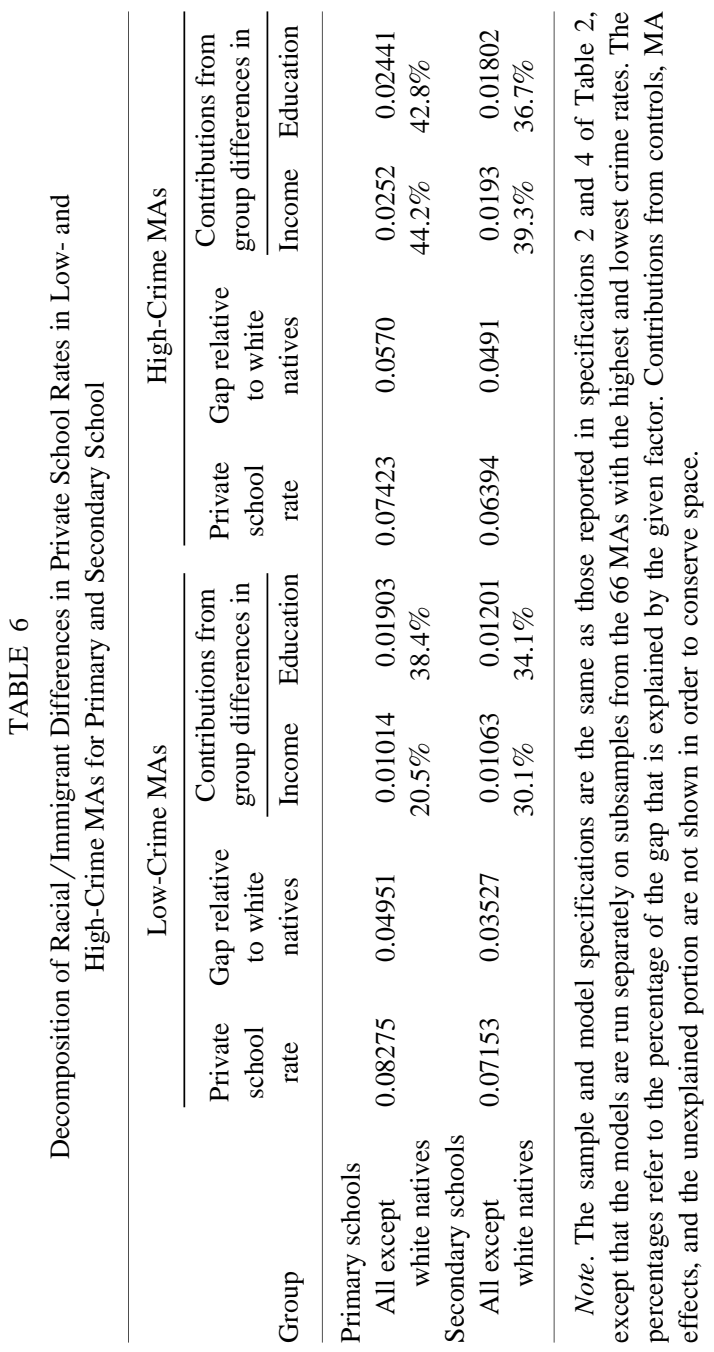


of the private school enrollment gap that can be explained by income rises from $20.5 \%$ in low-crime MAs to $44.2 \%$ in high-crime MAs. In secondary schools, the corresponding numbers are 30.1 and $39.3 \%$. It appears that family income becomes a more critical factor in creating a wedge between private enrollment rates of white natives and all others in MAs with higher crime rates.

Table 7 shows the analogous decomposition analysis when separate enrollment models are estimated for MAs with high and low spending per pupil in public schools. In low-expenditure MAs, the enrollment gap between white natives and all others is slightly higher than in high-expenditure MAs. This pattern may result from a greater financial ability of white natives to respond to low spending in public schools by sending their children to private school. The decomposition analysis certainly points in this direction. Family income can explain considerably more of the enrollment gap in MAs with low public school spending than in MAs with high spending. For instance, in primary school, family income can explain fully $42.1 \%$ of the enrollment gap in low-expenditure MAs, compared to just $24.5 \%$ of the gap in high-expenditure MAs. Similar but slightly weaker patterns appear in secondary school. The explanatory power of parental education in high- and low-expenditure MAs does not vary as much, and the variations work in opposite directions in primary and secondary schools.

Together, these tables point in the same direction: the impact of family income on the private school enrollment gap between white natives and others varies in important ways across MAs. In MAs where the motivation of parents to send their children to private school might be higher, family income becomes a more important explanatory factor in explaining why white natives are more likely to send their children to private schools than other parents. Specifically, family income became a more important factor in MAs with relatively high crime rates and MAs with relatively low spending per pupil in public schools.

\section{CONCLUSION}

The recent literature on private schools suggests that private schools may improve academic outcomes among students, in particular minority students. Given this proposition, it becomes important from the perspective of equal educational opportunity to understand how and why private school attendance varies by demographic groups.

The first question that the paper asked is: "How much do private school attendance rates rate across ethnic, racial, and immigrant groups?' We document quite large variations in private school attendance rates between students in different categories of race, ethnicity, and immigrant status. For instance, in primary schools in 1990, private school attendance rates vary from just $4.5 \%$ among Hispanic immigrants to $17.8 \%$ among white immigrants. On average, natives are significantly more likely to attend private primary schools $(11.8 \%$ 


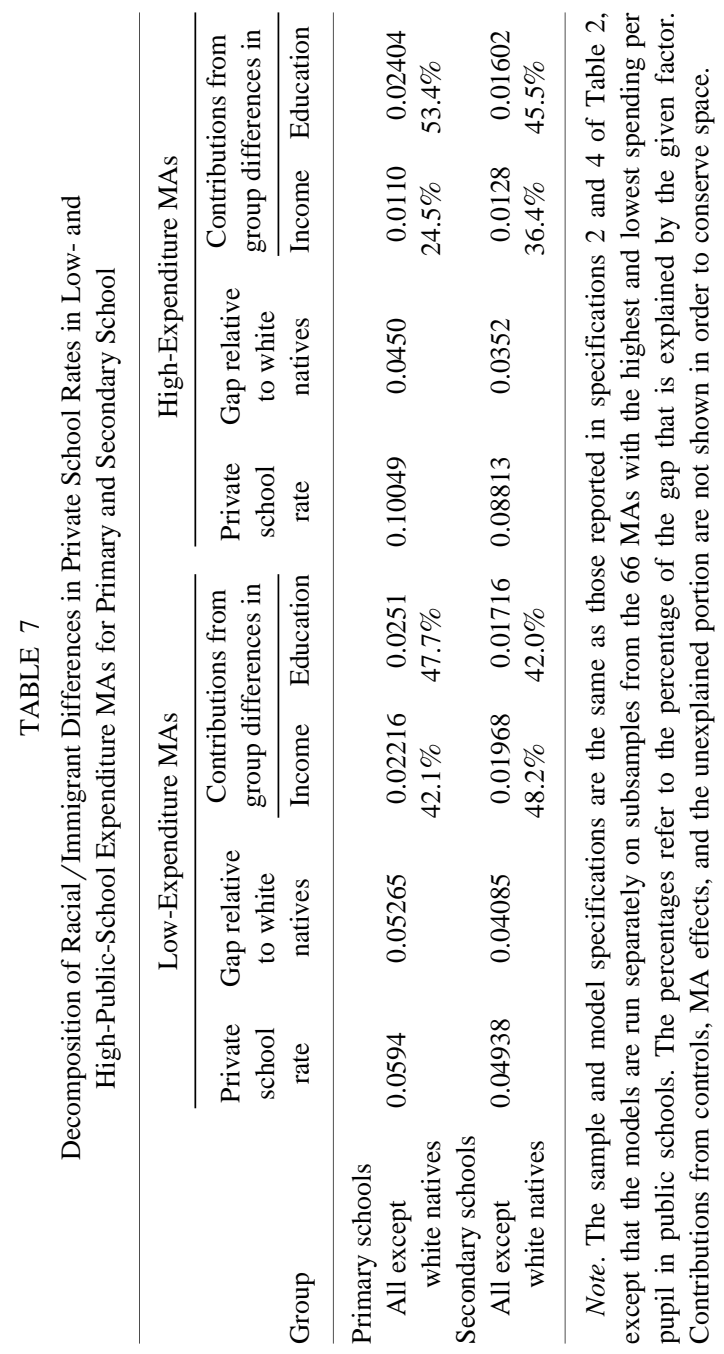


versus only $7.6 \%$ among immigrants). Similar gaps in private school attendance rates exist in secondary schools.

Another important question addressed in this paper concerns the underlying causes behind these gaps. Are the causes related to geography or personal traits of the families with school-aged children? If personal traits matter, does family income play a significant role, or do other factors, less amenable to direct policy intervention, such as parental education, play a dominant role?

Using a sample of 132 metropolitan areas from the 1990 Census, we estimate fixed effects regressions to control for unobserved traits of each metropolitan area. We find that group differences in parental education and family income per capita together can account for over $70 \%$ of the variation in mean private school attendance rates between white natives and all other groups taken together. Parental education appears to be the slightly more important explanatory factor, accounting for 43.7 and $37.2 \%$ of this variation for primary and secondary schools, respectively. However, group differences in family income per capita are also extremely important, accounting for 29.3 and $36.2 \%$ of the variation in primary and secondary schools.

Our main analysis uses fixed effects to control for all unobserved characteristics of MAs such as the crime rate and spending per pupil in public schools. However, it is possible that the explanatory power of family income and parental education could vary by MA. We found that the private school enrollment gap between white natives and all others varied by the type of MA. Family income seems to matter more in explaining the enrollment gap in MAs with high crime rates and low spending per pupil in public schools.

Our conclusion that overall parental education and family income can account for over $70 \%$ of the private school enrollment gap is tempered by the limitations of the Census data we used. The Census does not include information on the religious affiliation of families. In the late 1980s, Catholic schools accounted for slightly over half of private school enrollment, with other religious schools accounting for another third. (National Center for Education Statistics [14]). To some extent, the higher rates of private school choice that we have attributed to higher parental education and family income may in reality reflect religious background. This question deserves further research.

Our results hold some relevance for the debate currently raging over school vouchers, although they clearly cannot indicate how big vouchers would need to be to attain any desired rate of private school enrollment. During the 1990s, a number of school voucher programs, perhaps most notably in Cleveland and Milwaukee, enabled disadvantaged students to use public money to attend private schools. Florida implemented the first stage of a statewide program in 1999. A subtext behind these programs seems to be that modest financial vouchers will equalize the ability of students of low and high socioeconomic status to enjoy the benefits of a private education. 
Our results confirm that variations in family income can account for substantial portions of the intergroup variations in private school attendance. However, we find it noteworthy that parental education explains as much or more of existing intergroup variation in attendance rates than does family income. We infer that a voucher program aimed to equalize the opportunity to attend private schools would have to do more than compensate for income differences between socioeconomic groups and would in addition have to compensate for variations in parental education. Our research, of course, cannot provide specific estimates of the subsidies required to equalize private school attendance rates among all groups. A tuition voucher will induce both income and substitution effects; our analysis of within-city variations in private school attendance rates identifies only the variation in private school attendance with respect to income, holding price constant. Because vouchers lower the price of attending private school, vouchers that equalize private school shares across groups need not be as large as implied by the enrollment:income relation estimated in this paper.

Our analyses by subsamples of MAs also indicated that income was a relatively more important determinant of the private school enrollment gap between white natives and all others in high-crime MAs and low-publicschool-expenditure MAs. This suggests that vouchers aimed at equalizing private school attendance between white natives and minorities might be more needed in these types of metropolitan areas.

More broadly speaking, our results raise questions about the definition of equal opportunity in education. Traditionally, this has meant equalizing resources among public schools, or more radically, reallocating resources to equalize student achievement among schools. But if it is true that private schools do a relatively good job of teaching minorities and students in urban areas, then the existing racial/immigrant gaps in private school attendance are worrisome. Perhaps the common definitions of equal opportunity in education should expand to incorporate equal access to private schools between immigrants and natives and among racial groups. Seen in this light, the task of equalizing educational opportunity may prove even more daunting than we might have thought.

\section{APPENDIX}

\section{Public School Expenditures per Pupil}

This variable is defined as expenditures per pupil in public elementary and secondary schools in the MA. It is adjusted using the Consumer Price Index to 1990 prices. We create this variable by using data by school district as reported in the Census of Governments 1992. Our MA-level data for spending per pupil 
were obtained by summing spending and enrollments for all school districts within a given county and then summing these to the MA level using the concordance between state and county codes and consolidated metropolitan statistical area codes provided on the USA Counties 1996 (CD-ROM).

For 9 of the 132 metropolitan areas, no spending data were available at the district level. With one exception, these were relatively small metropolitan areas. For these areas, we instead used spending per pupil at the state level derived from National Center for Education Statistics (1992, 1996). One of these nine areas, Johnson City, spanned two states (Tennessee and Virginia). In this case we took a weighted average across these two states based on the population shares in our 1980 and 1990 Census data. The other metropolitan areas for which state-level data were substituted were Baltimore, Maryland; Fayetteville, Greensboro-Winston-Salem-High Point, and Raleigh-Durham, all three in North Carolina; Honolulu, Hawaii; Knoxville, Tennessee; and Norfolk and Richmond, both in Virginia.

\section{Crime Rate}

The crime rate is defined as the annual number of serious crimes per 1000 residents in each county, calculated from the USA Counties 1996. Serious crimes include murder and nonnegligent manslaughter, forcible rape, robbery, aggravated assault, burglary, larceny-theft, and motor vehicle theft. We aggregated these to the MA level using the concordance tables in Appendices C1 and C2 of USA Counties 1996.

TABLE A-1

Household Demographics by Racial/Immigrant Group

\begin{tabular}{lccc}
\hline & $\begin{array}{c}\text { Per-person } \\
\text { household } \\
\text { income } \\
(000 \mathrm{~s})\end{array}$ & $\begin{array}{c}\text { Proportion of } \\
\text { mothers with } \\
\text { college degree }\end{array}$ & $\begin{array}{c}\text { Proportion of } \\
\text { fathers with } \\
\text { college degree }\end{array}$ \\
\hline White natives & 13.09 & 0.21 & 0.32 \\
White immigrants & 12.03 & 0.25 & 0.42 \\
Black natives & 6.99 & 0.10 & 0.14 \\
Black immigrants & 6.89 & 0.09 & 0.16 \\
Hispanic natives & 7.25 & 0.06 & 0.10 \\
Hispanic immigrants & 5.14 & 0.04 & 0.08 \\
Asian natives & 14.13 & 0.38 & 0.47 \\
Asian immigrants & 8.49 & 0.23 & 0.33 \\
Other natives & 8.44 & 0.11 & 0.15 \\
Other immigrants & 7.08 & 0.09 & 0.22 \\
\hline
\end{tabular}




\section{REFERENCES}

1. J. R. Betts and R. W. Fairlie, "Does immigration induce 'native flight' from public schools into private schools?" manuscript, University of California, San Diego and Santa Cruz (1999).

2. J. Bound and H. J. Holzer, "Demand shifts, population adjustments, and labor market outcomes during the 1980s, " National Bureau of Economic Research Working Paper 5685 (1996).

3. R. J. Buddin, J. J. Cordes, and S. N. Kirby, School choice in California: who chooses private schools? Journal of Urban Economics, 44, 110-134 (1998).

4. A. S. Blinder, Wage discrimination: reduced form and structural variables, Journal of Human Resources, 8, 436-455 (1973).

5. J. R. Conlon and M. S. Kimenyi, Attitudes towards race and poverty in the demand for private education: the case of Mississippi, Review of Black Political Economy, 20, 5-22 (1991).

6. W. N. Evans and R. M. Schwab, Finishing high school and starting college: do Catholic schools make a difference? Quarterly Journal of Economics, 110(4), 941-974 (1995).

7. R. W. Fairlie and A. M. Resch, "Is there "white flight' into private schools? Evidence from the National Educational Longitudinal Survey,” University of California, Santa Cruz Working Paper (1999).

8. D. N. Figlio and J. A. Stone, Are private schools really better? Research in Labor Economics, 18, 115-140 (1999).

9. V. Henderson, P. Mieszkowski, and Y. Sauvageau, Peer group effects and educational production functions, Journal of Public Economics, 10, 97-106 (1978).

10. D. A. Jaeger, “Regional and local area impacts of immigration on natives' wages," Bureau of Labor Statistics Working Paper (1996).

11. H. Lankford and J. Wyckoff, "The effect of school choice and residential location on the racial segregation of elementary students," State University of New York-Albany Working Paper (1997).

12. S. Loeb, S. Turner, and D. Jaeger, "Coding geographic areas across census years: creating consistent definitions of metropolitan areas," manuscript, University of Michigan (1996).

13. G. S. Maddala, "Limited-Dependent and Qualitative Variables in Econometrics," Cambridge University Press, Cambridge, UK (1983).

14. National Center for Education Statistics. "Digest of Education Statistics-1991,' U.S. Govt. Printing Office, Washington, DC (1991).

15. D. Neal, The effects of Catholic secondary schooling on educational attainment, Journal of Labor Economics, 15, 98-123 (1997).

16. D. Neumark, Employers' discriminatory behavior and the estimation of wage discrimination, Journal of Human Resources, 23, 279-295 (1988).

17. R. Oaxaca, Male-Female Wage Differentials in Urban Labor Markets, International Economic Review, 14, 693-709 (1973).

18. R. Oaxaca and M. Ransom, On Discrimination and the Decomposition of Wage Differentials, Journal of Econometrics, 61, 5-21 (1994).

19. W. Sander and A. C. Krautmann, Catholic schools, dropout rates and educational attainment, Economic Inquiry, 33, 217-233 (1995).

20. A. A. Summers and B. L. Wolfe, Do schools make a difference? American Economic Review, 67, 639-652 (1977). 